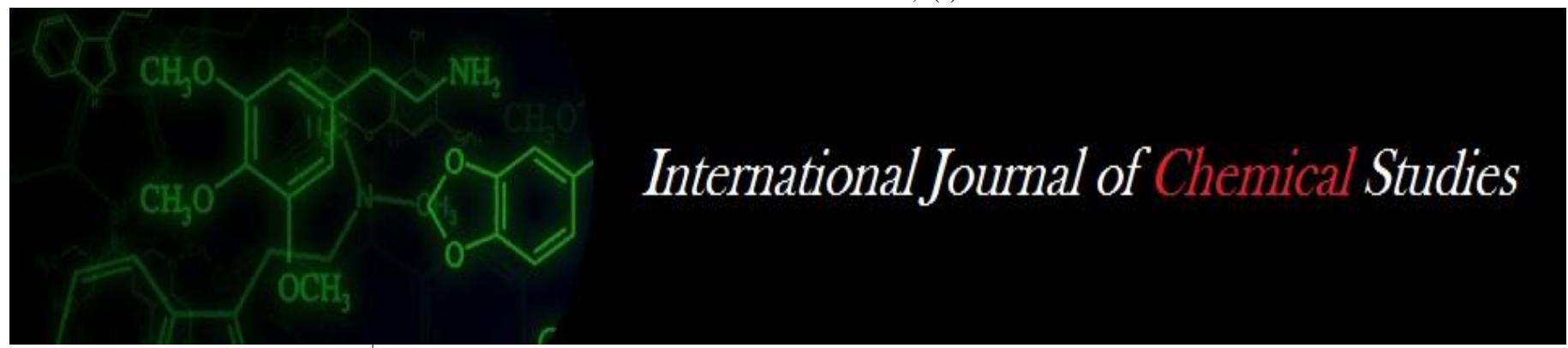

P-ISSN: 2349-8528

E-ISSN: 2321-4902

IJCS 2020; 8(1): 1358-1362

(C) 2020 IJCS

Received: 10-11-2019

Accepted: 12-12-2019

\section{HK Pankaja}

Department of Agricultural

Extension, UAS, GKVK,

Bangalore, Karnataka, India

\section{SV Suresha}

Department of Agricultural

Extension, UAS, GKVK,

Bangalore, Karnataka, India

NS Shivalinge Gowda

Department of Agricultural

Extension, UAS, GKVK

Bangalore, Karnataka, India

\section{Impact of swarna jayanthi gram swarozgar yojana (SGSY) on women empowerment}

\author{
HK Pankaja, SV Suresha and NS Shivalinge Gowda
}

DOI: https://doi.org/10.22271/chemi.2020.v8.i1s.8442

\begin{abstract}
The study was conducted in Bangalore Rural and Hassan districts of Karnataka state to find the extent of participation and socio-economic status of SGSY beneficiaries. From Bangalore Rural district Doddaballapura taluk and Hassan taluk from Hassan district was selected for the study. From each taluk 25 SGSY beneficiaries were selected, hence the total sample size of the study was 50 . The results indicated that majority (38\%) of the SGSY beneficiaries belongs to medium level participation category and low (40\%) socio-economic status group. A large number of them had middle school education (58\%), depending on farming $(90 \%)$, belonged to backward caste $(70 \%)$, nuclear family $(70 \%)$, had medium family size $(76 \%)$, socio-political participation $(60 \%)$, immovable assets $(40 \%)$ and equal per cent $(44 \%)$ of them belonged to low level of annual income and movable assets group respectively. The personal, communication and psychological characteristics explained to an extent of 31.10 percent of variation in EOP of SGSY beneficiaries.
\end{abstract}

Keywords: SGSY, women empowerment

\section{Introduction}

SGSY is one of the programme for self-employment initiated by the Government of India to bring the rural poor people above the poverty by providing them income generating assets through bank credit and government subsidy. The SGSY programme was launched on 1st April 1999 and emphasized on BPL families and financial support through bank credit and government subsidy. The programme has been funded by the centre and the state government in the ratio of 75:25 respectively. Poverty and unemployment are the major problems of any under developed countries, to which India is no exception. In India, being a developing nation, has approx. $21.9 \%$ is below poverty line of its total population of 121.1 crores (Census, 2011) ${ }^{[5]}$. Among the various programmes launched for poverty alleviation the SGSY seems arguable the more viable comprehensive and bold initiative. The programme aims at the large number of micro enterprises especially for poor people in rural areas and the poverty line men (BPL) to assist the families above the poverty line through generation of assets through bank credit and government subsidy. The beneficiary families (known as Swarozgaries) may be individuals or groups (SHGs). So, the objective of the programme is to bring the Swarozgaries above the poverty line by ensuring appreciable sustaining level of income over a period of time, by organizing the rural poor into SHGs through the process of social mobilization, their training and capacity building and provision of income generating assets. Therefore, an effort has been made in this study to measure the extent of participation (EOP) of the beneficiaries in the programme, their socio-economic status (SES) of beneficiaries and characteristics that influence their participation, so that it could be utilized for improving the other development programmes.

\section{Objectives}

1. To study the extent of participation and socio-economic status of SGSY beneficiaries.

2. To find out the socio-economic characteristics of SGSY beneficiaries.

3. To know the relationship between extent of participation and the independent variables of SGSY beneficiaries.

\section{HK Pankaja}

Department of Agricultural

Extension, UAS, GKVK,

Bangalore, Karnataka, India 


\section{Methodology}

The study was conducted in Bangalore rural and Hassan Districts of Karnataka. Doddaballapura and Hassan taluks were selected, from each taluk three villages were selected. From each district twenty five beneficiaries were selected, thus the total number of respondents for the study was 50 . Data were collected using pre tested interview schedule through personal interview method and the collected data were analysed using the suitable statistical tools such as percentage analysis, mean, standard deviation, correlation, regression, logistic regression analysis and path analysis.

\section{Results and Discussion \\ Overall distribution of SGSY beneficiaries based on their EOP and SES}

Data in table 1 presents the overall distribution of respondents based on the EOP and SES. As it could be observed from the table that 38 per cent of the beneficiaries possess medium level followed by low (32\%) and high (30\%) level of participation categories. According to their SES, two-fifth of them $(40 \%)$ had low SES followed by high (34\% and medium (26\%) categories.

The data of table 1 also highlights the cross tabulation of SES and EOP of SGSY beneficiaries. The respondents who possess high SES had high $(58.8 \%)$ level of participation followed by medium (35.3\%) and low (5.9\%) categories.
Whereas, in case of medium level SES, an equal percent $(38.5 \%)$ of them possess high and medium level of participation followed by low $(23.1 \%)$ category. The beneficiaries with low SES had low (60\%) and medium $(40 \%)$ participation in SGSY programme.

Table 1: Overall distribution of SGSY beneficiaries based on their SES and EOP

\begin{tabular}{|c|c|c|c|c|}
\hline Count of sorting & \multicolumn{3}{|c|}{ Extent of Participation } & \multirow{2}{*}{ Grand Total } \\
\cline { 1 - 4 } Socio-economic Status & Low & Medium & High & \\
\hline Low & $12(60.0)$ & $8(40.0)$ & - & $20(40.0)$ \\
\hline Medium & $3(23.1)$ & $5(38.5)$ & $5(38.5)$ & $13(26.0)$ \\
\hline High & $1(5.9)$ & $6(35.3)$ & $10(58.8)$ & $17(34.0)$ \\
\hline Grand Total & $16(32.0)$ & $19(38)$. & $15(30.0)$ & $50(100.0)$ \\
\hline
\end{tabular}

\section{Socio-economic Status characteristics of SGSY beneficiaries}

The table 2 reveals that majority (58\%) of SGSY beneficiaries had middle school level followed by primary school $(32 \%)$ level of education, 90 per cent of them depend on farming, 70 per cent belonged to backward caste, 70 per cent of them possessed nuclear type of family, medium family size (76\%), equal per cent (44\%) of them belonged to low level of annual income and movable assets group respectively, possessed medium level $(60 \%)$ of socio-political participation and belonged to high (40\%) immovable assets possession group.

Table 2: Socio-economic status characteristics of SGSY beneficiaries $n=50$

\begin{tabular}{|c|c|c|c|}
\hline Sl. No. & Characteristics & No. & Percent \\
\hline \multirow{9}{*}{1.} & Education & & \\
\hline & a. $\quad$ Illiterate & - & - \\
\hline & b. $\quad$ Functionally literate & - & - \\
\hline & c. $\quad$ Primary school $\left(1\right.$ to $\left.4^{\text {th }}\right)$ & 16 & 32.00 \\
\hline & d. $\quad$ Middle school $\left(5^{\text {th }}\right.$ to $\left.7^{\text {th }}\right)$ & 29 & 58.00 \\
\hline & e. $\quad$ High school $\left(8^{\text {th }}\right.$ to $\left.10^{\text {th }}\right)$ & 5 & 10.00 \\
\hline & f. $\quad$ P.U.C $\left(11^{\text {th }}\right.$ to $\left.12^{\text {th }}\right)$ & - & - \\
\hline & g. $\quad$ Graduate & - & - \\
\hline & h. $\quad$ Post graduate & - & - \\
\hline \multirow{8}{*}{2.} & Occupation & & \\
\hline & a. Unskilled labour & - & - \\
\hline & b. Semi-skilled & - & - \\
\hline & $\begin{array}{ll}\text { c. } & \text { Skilled }\end{array}$ & 5 & 10.00 \\
\hline & d. $\quad$ Farming & 45 & 90.00 \\
\hline & e. $\quad$ Business & - & - \\
\hline & $\begin{array}{ll}\text { f. } & \text { Professional } \\
\end{array}$ & - & - \\
\hline & g. $\quad$ Government job & - & - \\
\hline \multirow{5}{*}{3.} & \begin{tabular}{|r|} 
Government job Caste \\
\end{tabular} & & \\
\hline & a. $\quad$ Scheduled caste & 9 & 18.00 \\
\hline & b. $\quad$ Scheduled tribe & 5 & 10.00 \\
\hline & c. Backward caste & 35 & 70.00 \\
\hline & d. $\quad$ Forward caste & 1 & 2.00 \\
\hline \multirow{9}{*}{4.} & $\begin{array}{r}\text { Family } \\
\end{array}$ & & \\
\hline & a. $\quad$ Family Type & & \\
\hline & i. Nuclear Family & 35 & 70.00 \\
\hline & ii. Joint Family & 15 & 30.00 \\
\hline & b. $\quad$ Family Size & & \\
\hline & a. $\quad$ Small & 6 & 12.00 \\
\hline & b. $\quad$ Medium & 38 & 76.00 \\
\hline & c. Large & 6 & 12.00 \\
\hline & d. Very large & - & - \\
\hline \multirow{4}{*}{5.} & Annual Income & & \\
\hline & Low & 22 & 44.00 \\
\hline & Medium & 7 & 14.00 \\
\hline & High & 21 & 42.00 \\
\hline \multirow{3}{*}{6.} & Socio-political participation & & \\
\hline & Low & 7 & 14.00 \\
\hline & Medium & 30 & 60.00 \\
\hline
\end{tabular}




\begin{tabular}{|l|c|c|c|}
\hline & High & 13 & 26.00 \\
\hline \multirow{4}{*}{7.} & Movable assets & & \\
\cline { 2 - 4 } & Low & 22 & 44.00 \\
\cline { 2 - 4 } & Medium & 11 & 22.00 \\
\hline \multirow{4}{*}{8.} & High & 17 & 34.00 \\
\cline { 2 - 4 } & Immovable assets & 17 & 34.00 \\
\cline { 2 - 4 } & Low & 13 & 26.00 \\
\cline { 2 - 4 } & Medium & 20 & 40.00 \\
\hline
\end{tabular}

Relationship between extent of participation and the independent variables of SGSY beneficiaries

Correlation and regression analysis between EOP and independent variables of SGSY programme beneficiaries

The extent of participation of SGSY programme beneficiaries was found to be positively correlated with their mass media participation, localite-cosmopoliteness, and innovative proneness, level of aspiration, achievement motivation, decision making ability, management orientation and time management (table 3). However, the remaining variables were found to be not related with extent of participation.

As seen from table 3, out of 15 variables fitted in the multiple linear regression analysis only one of them, mass media participation contributed significantly to the prediction of extent of participation. However, 15 variables explained to an extent of 31.09 per cent of variation in the extent of participation of beneficiaries and the R2 was found to be nonsignificant.

Table 3: Correlation and regression analysis of Extent of Participation and personal, communication and psychological characteristics of SGSY programme beneficiaries $n=50$

\begin{tabular}{|c|c|c|c|c|c|}
\hline \multirow{2}{*}{ Sl. No. } & \multirow{2}{*}{ Characteristics } & \multicolumn{4}{|c|}{ SGSY } \\
\cline { 3 - 6 } & & ' $\mathbf{r}^{\prime}$ values & 'b' values & S. E. & 't' values \\
\hline 1. & Age & $-0.1092 \mathrm{NS}$ & 0.2273 & 0.1503 & 1.5120 \\
\hline 2. & Marital status & $-0.1303 \mathrm{NS}$ & -10.0688 & 6.8365 & -1.4728 \\
\hline 3. & Family dependency ratio & $0.2012 \mathrm{NS}$ & -0.0196 & 0.1608 & -0.1216 \\
\hline 4. & Family labour force & $-0.1445 \mathrm{NS}$ & -2.7879 & 1.7043 & -1.6358 \\
\hline 5. & Mass media participation & $0.2785^{*}$ & 2.7158 & 1.6524 & $1.9835^{*}$ \\
\hline 6. & Localite-cosmopoliteness & $0.3106^{*}$ & -0.1680 & 0.7058 & -0.2380 \\
\hline 7. & Innovative proneness & $0.3260^{*}$ & 1.4302 & 1.5678 & 0.9122 \\
\hline 8. & Scientific orientation & $0.1129 \mathrm{NS}$ & 0.9332 & 0.7298 & 1.2788 \\
\hline 9. & Economic motivation & $0.2594 \mathrm{NS}$ & -1.1010 & 2.6227 & -0.4198 \\
\hline 10. & Level of aspiration & $0.2917^{*}$ & -0.1571 & 1.0194 & -0.1541 \\
\hline 11. & Deferred gratification & $0.0272 \mathrm{NS}$ & -0.8891 & 0.7736 & -1.1493 \\
\hline 12. & Achievement motivation & $0.3270^{*}$ & 0.0956 & 0.5902 & 0.1620 \\
\hline 13. & Decision making ability & $0.2827^{*}$ & 1.3052 & 1.8941 & 0.6891 \\
\hline 14. & Management orientation & $0.2929^{*}$ & -1.0544 & 1.6580 & -0.6359 \\
\hline 15. & Time management & $0.4106^{* *}$ & 0.2110 & 0.2051 & 1.0288 \\
\hline
\end{tabular}

$\mathrm{R}^{2}=0.3109$

$\mathrm{F}=1.0224$

** Significant at 1 per cent level

* Significant at 5 per cent level NS - Non significant

Logistic regression analysis between EOP and independent variables of SGSY programme beneficiaries

The review of results of logistic regression analysis in table 4 showed that mass media participation, scientific orientation, decision making ability and time management were significant in contributing to the participation of SGSY programme beneficiaries. A cursory glance at the same table also revealed that the logistic model correctly predicted $72 \%$ of the cases and the chi-square value was found to be nonsignificant. The co-efficient of decision-making ability was found to be significant. This indicated that, as 1 unit increase in the decision making ability of SGSY beneficiaries would prompt the beneficiaries to participate in the programme by 4 times.

Table 4: Logistic regression analysis between Extent of Participation and personal, communication and psychological characteristics of SGSY programme beneficiaries $\mathrm{n}=50$

\begin{tabular}{|c|c|c|c|c|}
\hline Sl. No. & Characteristics & b value & Wald & Exp (B) \\
\hline 1. & Age & 0.022 & 0.1094 & 1.0219 \\
\hline 2. & Marital status & -0.868 & 0.3076 & 0.4199 \\
\hline 3. & Family dependency ratio & 0.008 & 0.0404 & 1.0079 \\
\hline 4. & Family labour force & -1.277 & 2.3279 & 0.2790 \\
\hline 5. & Mass media participation & 0.638 & $6.7251^{* *}$ & 1.8921 \\
\hline 6. & Localite-cosmopoliteness & -0.020 & 0.0175 & 0.9799 \\
\hline 7. & Innovative proneness & 0.155 & 0.1629 & 1.1673 \\
\hline 8. & Scientific orientation & 0.473 & $3.9666^{*}$ & 1.6045 \\
\hline 9. & Economic motivation & 0.309 & 0.2420 & 1.3619 \\
\hline 10. & Level of aspiration & -0.351 & 1.4226 & 0.7042 \\
\hline 11. & Deferred gratification & -0.270 & 1.6399 & 0.7636 \\
\hline 12. & Achievement motivation & 0.052 & 0.1352 & 1.0531 \\
\hline
\end{tabular}




\begin{tabular}{|c|c|c|c|c|}
\hline 13. & Decision making ability & 1.604 & $4.8661^{*}$ & 4.9714 \\
\hline 14. & Management orientation & -0.527 & 1.7580 & 0.5904 \\
\hline 15. & Time management & -0.356 & $5.2980^{*}$ & 0.7008 \\
\hline
\end{tabular}

Chi-square 23.036NS

Cases correctly predicted $72.00 \%$.

** Significant at 1 per cent level

* Significant at 5 per cent level

Table 5: Direct, indirect and largest indirect effects of personal, communication and psychological variables on Extent of Participation of SGSY beneficiaries $n=50$

\begin{tabular}{|c|c|c|c|c|c|c|c|}
\hline $\begin{array}{l}\text { Sl. } \\
\text { No. }\end{array}$ & Independent Variables & $\begin{array}{c}\text { Correlation Co- } \\
\text { efficient }\end{array}$ & $\begin{array}{c}\text { Direct } \\
\text { effect }\end{array}$ & Rank & $\begin{array}{c}\begin{array}{c}\text { Total indirect } \\
\text { effect }\end{array} \\
\end{array}$ & Rank & $\begin{array}{c}\text { Three largest indirect effect channelized } \\
\text { through }\end{array}$ \\
\hline 1. & $\begin{array}{l}\text { Mass media participation } \\
\left(\mathrm{X}_{5}\right)\end{array}$ & $0.2785^{*}$ & 0.1008 & 2 & 0.1777 & 8 & $\begin{array}{c}0.1162-X_{10} \\
0.0768-X_{12} \\
0.0136-X_{7}\end{array}$ \\
\hline 2. & $\begin{array}{l}\text { Localite-cosmopoliteness } \\
\qquad\left(\mathrm{X}_{6}\right)\end{array}$ & $0.3106^{*}$ & 0.112 & 1 & 0.1986 & 7 & $\begin{array}{c}0.1035-X_{13} \\
0.1007-X_{14} \\
0.093-X_{7}\end{array}$ \\
\hline 3. & Innovative proneness $\left(\mathrm{X}_{7}\right)$ & $0.3260 *$ & -0.1066 & 8 & 0.4326 & 2 & $\begin{array}{c}0.2092-X_{5} \\
0.1013-X_{12} \\
0.0966-X_{7}\end{array}$ \\
\hline 4. & Level of aspiration $\left(\mathrm{X}_{10}\right)$ & $0.2917 *$ & -0.1063 & 7 & 0.397 & 3 & $\begin{array}{l}0.2282-X_{14} \\
0.1063-X_{10} \\
0.0647-X_{15}\end{array}$ \\
\hline 5. & $\begin{array}{l}\text { Achievement motivation } \\
\left(\mathrm{X}_{12}\right)\end{array}$ & $0.3270 *$ & 0.0251 & 3 & 0.3019 & 5 & $\begin{array}{c}0.2148-\mathrm{X}_{15} \\
0.1018-\mathrm{X}_{10} \\
0.0815-\mathrm{X}_{5}\end{array}$ \\
\hline 6. & $\begin{array}{l}\text { Decision making ability } \\
\qquad\left(\mathrm{X}_{13}\right)\end{array}$ & $0.2827 *$ & 0.0099 & 4 & 0.2728 & 6 & $\begin{array}{c}0.2011-\mathrm{X}_{5} \\
0.1005-\mathrm{X}_{12} \\
0.0831-\mathrm{X}_{7}\end{array}$ \\
\hline 7. & $\begin{array}{l}\text { Management orientation } \\
\qquad\left(\mathrm{X}_{14}\right)\end{array}$ & $0.2929 *$ & -0.0487 & 5 & 0.3416 & 4 & $\begin{array}{l}0.2487-X_{14} \\
0.1615-X_{10} \\
0.1331-X_{15}\end{array}$ \\
\hline 8. & Time management $\left(\mathrm{X}_{15}\right)$ & $0.4106 * *$ & -0.1021 & 6 & 0.5127 & 1 & $\begin{array}{c}0.4283-X_{6} \\
0.1636-X_{10} \\
0.1421-X_{15}\end{array}$ \\
\hline
\end{tabular}

Direct and indirect effects of selected personal, communication and psychological variables on extent of participation of SGSY beneficiaries

The results of path analysis are presented in table 5 and it could be seen from the table that Localite-cosmopoliteness $\left(\mathrm{X}_{6}\right)$ was found to influence the extent of participation of SGSY beneficiaries with the magnitude of 0.112 . Out of eight variables selected, 4 variables had positive direct effect and remaining four variables had negative direct effect on extent of participation of SGSY beneficiaries.

The variables like time management $\left(X_{15}\right)$, Innovative proneness $\left(\mathrm{X}_{7}\right)$, level of aspiration $\left(\mathrm{X}_{10}\right)$, management orientation $\left(\mathrm{X}_{14}\right)$, Achievement motivation $\left(\mathrm{X}_{12}\right)$, Decisionmaking ability $\left(\mathrm{X}_{13}\right)$, Localite-cosmopoliteness $\left(\mathrm{X}_{6}\right)$ and mass media participation $\left(\mathrm{X}_{5}\right)$ had higher indirect effects on the extent of participation of SGSY beneficiaries.

Out of 24 substantial indirect effects, 5 variables each channelled through level of aspiration $\left(\mathrm{X}_{10}\right)$, 4 variables each channeled through Innovative proneness $\left(\mathrm{X}_{7}\right)$ and time management $\left(\mathrm{X}_{15}\right), 3$ variables channeled through mass media participation $\left(\mathrm{X}_{5}\right)$, Achievement motivation $\left(\mathrm{X}_{12}\right)$ and management orientation $\left(\mathrm{X}_{14}\right)$ and one variable each channeled through Localite-cosmopoliteness $\left(\mathrm{X}_{6}\right)$ and Decision making ability $\left(\mathrm{X}_{13}\right)$. The residual value was 0.662 .

\section{Conclusion}

The beneficiaries with high SES had high level of participation and also with medium level SES exerted high and medium level of participation in rural development programme like SGSY which are mainly based on the felt needs of the beneficiaries. The possession of high level managerial ability of the beneficiaries, which depends upon one's ability to take risk and actively involved in the activities of programme periodically helps them to improve their social status, annual income, health status, social participation and knowledge on advantages of programmes-schemes present in social institutions and line departments. Thus, it can be concluded from the research results that there is an improvement in the socio- economic status of women beneficiaries after the implementation of the poverty alleviation programme SGSY.

\section{References}

1. Chethana MP. Impact of Stree Shakthi programme on farmwomen in Tumkur District. M.Sc. (Agri.) thesis (Unpub.), Univ. Agril. Sci., Bangalore, 2005.

2. Manjula Malagi. Decision making and participation of farmwomen in watershed development programme. 
M.Sc. (Agri.) thesis (Unpub.), Univ. Agril. Sci., Bangalore, 2003.

3. Souvik Ghosh, People's participation in watershed management. Agricultural Extension Review. 2004; 16(3):27-30.

4. Trivedi G. Measurement analysis of socio-economic status in rural families Ph.D. Thesis (Unpub.), Indian Agricultural Research Institute, New Delhi, 1963.

5. www.censusindia.gov.in 